STUDIA I PRACE WYDZIAŁU NAUK EKONOMICZNYCH I ZARZĄDZANIA nr 40, t. 1

\author{
Jerzy Dudziński ${ }^{*}$ \\ Jarosław Narękiewicz \\ Uniwersytet Szczeciński
}

\title{
KIERUNKI ZMIAN CEN W HANDLU MIĘDZYNARODOWYM A SYTUACJA EKONOMICZNA KRAJÓW ROZWIJAJĄCYCH SIĘ W XXI WIEKU (NA PRZYKŁADZIE AFRYKI)
}

\section{Streszczenie}

W artykule dokonano próby oceny wpływu zmian cen w handlu międzynarodowym w XXI wieku na sytuację gospodarczą krajów rozwijających się i możliwości zwiększenia eksportu państw dysponujących znacznymi zasobami surowców i żywności (w tym zwłaszcza Afryki). W latach 2003-2011 nowe relacje cenowe znalazły swoje odzwierciedlenie w zdecydowanie wyższej dynamice cen surowców i żywności niż dóbr przetworzonych, ale od 2012 roku sytuacja uległa wyraźnemu odwróceniu.

Z przeprowadzonych badań wynika, że kraje rozwijające się są znacznie bardziej uzależnione od eksportu surowców i żywności niż kraje rozwinięte gospodarczo, a więc silniej reagują na wahania cen dóbr podstawowych. Bardzo dobre wyniki gospodarcze krajów Afryki w pierwszej dekadzie XXI wieku spowodowały pojawienie się głosów o konieczności rewizji tradycyjnego podejścia do kierunków rozwoju ekonomicznego krajów o surowcowo-rolnej strukturze wywozu. Sytuacja panująca w obecnej dekadzie, a także przedstawiane prognozy cen i tempa rozwoju ekonomicznego wskazują jednak na znaczną aktualność tez tradycyjnego podejścia ekonomicznego.

Słowa kluczowe: ceny światowe, kraje Afryki, dywersyfikacja eksportu

\footnotetext{
*Adres e-mail: jdudzi@wneiz.pl.

** Adres e-mail: joten@wneiz.pl.
} 


\section{Wprowadzenie}

Silna zależność krajów rozwijających się od wywozu surowców i żywności oraz negatywne skutki tego zjawiska budziły od dawna zainteresowanie w pracach naukowych oraz działalności organizacji międzynarodowych (np. UNCTAD). Wysoka dynamika cen dóbr podstawowych oraz wyraźna poprawa ich relacji do cen dóbr przetworzonych w pierwszej dekadzie XXI wieku spowodowały z kolei, że zaczęto z rezerwą podchodzić do tez głoszących konieczność dywersyfikacji eksportu (struktury towarowej) $\mathrm{i}$ industrializacji gospodarki w krajach rozwijających się. Sytuacja panująca w drugiej dekadzie XXI wieku (bezwzględny i relatywny spadek cen żywności) oraz prognozy kierunków ruchu cen w najbliższej przyszłości zmuszają jednak do głębszej analizy tego zagadnienia.

Celem opracowania jest próba oceny wpływu cen surowców i żywności na rozwój eksportu i gospodarki krajów rozwijających się w kontekście założeń tradycyjnej teorii ekonomii, międzynarodowych stosunków ekonomicznych i ekonomii rozwoju, głoszącej konieczność dywersyfikacji eksportu i industrializacji gospodarki, jako metody „ucieczki od pogarszających się terms of trade”. Badania zostały przeprowadzone na przykładzie krajów Afryki, a więc regionu najbardziej reprezentatywnego dla państw silnie uzależnionych od eksportu surowców i żywności.

W pierwszej części opracowania przedstawiono w syntetycznej formie główne założenia tradycyjnej teorii ekonomii dotyczące kierunków transformacji gospodarki krajów rozwijających się. W drugiej ukazano kierunki wpływu cen na dynamikę eksportu i wzrostu gospodarczego w pierwszej dekadzie XXI wieku. W ostatniej, trzeciej części przedstawiono rozważania dotyczące skutków ruchu cen w obecnej dekadzie oraz przewidywanych tendencji rozwojowych wybranych aspektów gospodarki krajów rozwijających się.

Zakres czasowy badań obejmuje w zasadzie lata 2001-2013. W przypadku cen zaprezentowano również dostępne dane sięgające II kwartału 2014 roku. Przedstawione prognozy (głównie IMF) dotyczą zwykle drugiej połowy obecnej dekady. W pracy zastosowano metodę statystyczno-opisową, a wykorzystane dane źródłowe pochodzą przede wszystkim z opracowań (raportów) UNCTAD i IMF. 


\section{Ruch cen surowców i żywności a sytuacja ekonomiczna krajów rozwijających się}

Problematyka silnej zależności krajów rozwijających się od eksportu surowców i żywności oraz wiążących się z tym negatywnych konsekwencji była od dawna poruszana w literaturze światowej. Na szczególną uwagę zasługuje w tym względzie tzw. teoria Prebischa-Singera, stworzona w połowie ubiegłego wieku. Wskazywała ona na zjawisko strukturalnego pogarszania się relacji cen dóbr podstawowych do przetworzonych. W efekcie notuje się długookresowy proces pogarszania się terms of trade krajów rozwijających się, co tłumaczy ich trudną - na ogół - sytuację gospodarczą ${ }^{1}$.

Choć tezy wspomnianej teorii były niekiedy kontestowane, zwłaszcza w okresach relatywnej zwyżki cen surowców (głównie w latach 70. ubiegłego wieku), to jednak ukazane podejście dominowało $\mathrm{w}$ literaturze przedmiotu². Za przyczynę długookresowego pogarszania się terms of trade krajów rozwijających się uznaje się relatywny spadek popytu na żywność i surowce rolne wraz ze wzrostem poziomu życia ludności (prawo Engla), a także postęp naukowo-techniczny powodujący zmniejszenie zużycia surowców na jednostkę produktu finalnego. Wśród przyczyn wymienia się także wzrost znaczenia usług we współczesnej gospodarce, które również wiążą się z relatywnie mniejszym zużyciem surowców.

Negatywny wpływ wspomnianych wyżej zjawisk na rozwój ekonomiczny krajów rozwijających się wynika z faktu ich dużej zależności od wywozu dóbr podstawowych ${ }^{3}$. Co więcej, dość często obserwuje się także koncentrację eksportu na niewielkiej liczbie towarów czy wręcz tzw. monoeksport. Zjawiska te są o tyle niekorzystne, że - jak wykazują wyniki badań prezentowanych w literaturze przedmiotu

${ }^{1}$ Por. np. N. Spatafora, I. Tytell, Commodity Terms of Trade: The History of Booms and Busts, „IMF Working Paper”, September 2009; Evaluation on Terms of Trade, w: Trade and Development Report, UNCTAD, New York-Geneva 2005; J. Dudziński, Ceny rynku międzynarodowego. Tendencje i mechanizm, Wydawnictwo Naukowe Uniwersytetu Szczecińskiego, Szczecin 1998, s. 83-89.

2 Por. np. J.A. Ocampo, M. Parra, The Terms of Trade for Commodities in the Twentieth Century, „CEPAL Review” No. 79, April 2003. W polskiej literaturze problem ten omawia m.in. A. Budnikowski, Międzynarodowe stosunki gospodarcze, PWE, Warszawa 2001, s. 376-377.

${ }^{3}$ W XXI wieku spośród 141 krajów rozwijających się, aż 95 charakteryzowało się udziałem surowców i żywności w eksporcie przekraczającym 50\% (por. Commodity Dependence and International Commodity Prices, w: Towards Human Resilience: Sustaining MDG Progress in an Age of Economic Uncertainty, UNDP, New York 2011, s. 58). 
- współczynnik korelacji między tempem wzrostu gospodarczego (dynamika PKB) i cenami dóbr podstawowych na rynku światowym wynosi aż $0,87^{4}$.

Dodatkowym czynnikiem w dużym stopniu negatywnie oddziałującym na sytuację ekonomiczną krajów rozwijających się są bardzo silne wahania cen surowców i żywności. Wspomniane fluktuacje wiążą się z niską elastycznością popytu na dobra podstawowe, przy zarazem małej elastyczności ich podaży na rynku światowym. Ważną rolę odgrywają ograniczenia wynikające z wpływu czynników przyrodniczych oraz długookresowy cykl inwestycji w górnictwie 5 . Niekiedy znaczny wpływ mogą mieć również czynniki polityczne (np. w przypadku tranzytu). Tworzenie dużych zapasów surowców i żywności, mogących wpływać kompensująco na wahania cen, utrudniają z kolei relatywnie znaczne koszty magazynowania wielu artykułów. Istotne znaczenie mają też kwestie zmian kursu walutowego ${ }^{6}$.

Silne wahania cen eksportowych destabilizują dodatkowo sytuację gospodarczą producentów surowców i żywności ${ }^{7}$, kształtującą się - jak wspomniano - niekorzystnie na skutek długookresowej tendencji pogarszania się terms of trade. Kraje rozwijające się mają więc bardzo duże trudności z wygospodarowaniem środków finansowych na cele rozwojowe, co z kolei ogranicza możliwości zwiększenia tempa wzrostu gospodarczego. Dobrze oddaje tę sytuację znane stwierdzenie wybitnego ekonomisty, zajmującego się problematyką krajów rozwijających się, R. Nurksego, który bardzo trafnie oddał istotę wspomnianej zależności, mówiąc, iż „kraj jest biedny, bo jest biedny".

W literaturze od dawna wskazuje się zatem na konieczność dywersyfikacji struktury produkcji i eksportu krajów rozwijających się. Szczególnie akcentuje się kwestię konieczności rozwoju przemysłu przetwórczego. Pozwoliłoby to bowiem złagodzić negatywne skutki nadmiernej specjalizacji surowcowo-rolnej. Znaczną

${ }^{4}$ Commodity Markets Review, IMF, October 2013, s. 2-3; Commodity Dependence..., s. 68.

${ }^{5}$ Por. S. Page, A. Hewitt, World Commodity Prices: Still a Problem for Developing Countries?, Overseas Development Institute, London 2011, s. 3-4.

${ }^{6}$ Por. Excessive Commodity Price Volatility: Macroeconomic Effects on Growth and Policy Options, UNCTAD, 30 April 2012, s. 1-37.

7 Warto podkreślić, że w XXI wieku roczna skala wahań cen surowców i żywności wyraźnie wzrosła z 9\% w latach 90. ubiegłego wieku do aż 26\% obecnie (por. Commodity Dependence..., s. 66. Wiąże się to m.in. z działalnością inwestorów finansowych na rynkach towarowych.

${ }^{8}$ Zob. np. M. Nissanke, Commodity Markets and Excess Volatility: Sources and Strategies to Reduce Adverse Development Impacts, CFC, University of London, London 2011; Price Volatility in 
rolę odgrywa w tym aspekcie działalność UNCTAD. W opracowaniach tej organizacji zwraca się także dodatkowo uwagę na tworzenie umów stabilizujących ceny surowców i żywności (międzynarodowe umowy towarowe) oraz konieczność bezpośredniej pomocy dla krajów najbiedniejszych (least developed countries) ${ }^{9}$.

\section{Rola Afryki w eksporcie światowym w pierwszej dekadzie XXI wieku}

Z grup krajów zaliczanych do rozwijających się niewątpliwie największe znaczenie dla eksportu światowego miały na początku XXI wieku kraje azjatyckie, których udział wyniósł w 2011 roku aż 33,9\%, podczas gdy na kraje rozwijające się Ameryki przypadło 6,1\%, a na kraje afrykańskie zaledwie 3,3\% ${ }^{10}$. Warto jednak podkreślić fakt, że o ile w latach 50. i 60. ubiegłego wieku odsetek w eksporcie światowym przypadający na kraje Afryki kształtował się na poziomie $6 \%-7 \%$, o tyle przez następne pięćdziesiąt lat rola tego kontynentu systematycznie malała (spadek udziału do około 2\%). Złożyło się na to wiele przyczyn, między innymi surowcowo-rolna specjalizacja eksportowa, przy utrzymujących się przez długi czas niekorzystnych relacjach cenowych.

Rysunek 1. Udział Afryki w eksporcie światowym w latach 2000-2011 (\%)

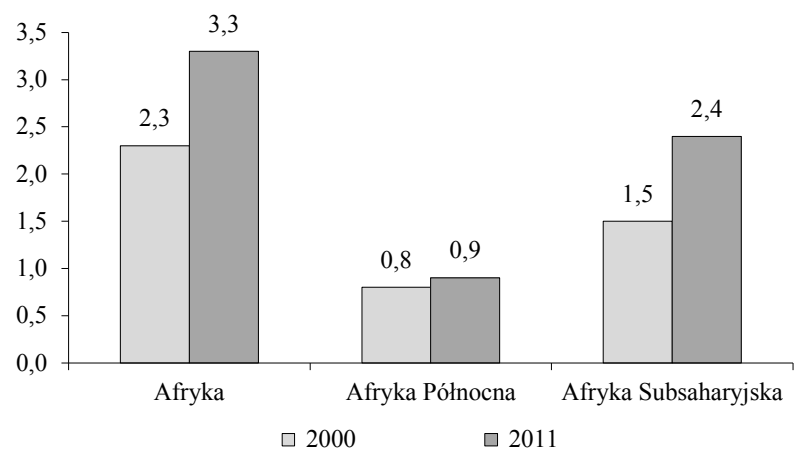

Źródło: UNCTAD statistical database...

Food and Agriculture Markets: Policy Responses, FAO, 2 June 2011; Commodities and Development Report, UNCTAD, New York-Geneva 2012, s. 7-11.

9 Szerzej na ten temat zob. A. Budnikowski, op.cit., s. 376-387.

${ }^{10}$ UNCTAD statistical database, http://unctadstat.unctad.org (dostęp 20.11.2014). 
W obecnym stuleciu Afryka zaczęła w sposób widoczny odrabiać dystans do pozostałych krajów rozwijających się. Jej udział w eksporcie światowym dość wyraźnie wzrósł z 2,3\% w 2000 roku do 3,3\% w 2011 roku (por. rysunek 1) ${ }^{11}$. Wynika to z faktu, że kraje Afryki osiągnęły w pierwszej dekadzie XXI wieku średnie tempo wzrostu eksportu w porównaniu z pozostałymi krajami rozwijającymi się (kraje Ameryki Łacińskiej i kraje azjatyckie) ${ }^{12}$. Znalazło to także swoje odzwierciedlenie w wyraźnie lepszych wskaźnikach wzrostu gospodarczego osiąganych w latach 2000-2010 przez kraje Afryki, w tym zwłaszcza Afryki Subsaharyjskiej, w porównaniu z ostatnią dekadą XX wieku (por. tabela 1).

Tabela 1. Średnie roczne tempo wzrostu eksportu i produktu krajowego brutto w krajach rozwijających się (\%)

\begin{tabular}{|l|c|c|c|c|c|c|}
\hline \multirow{2}{*}{ Region } & \multicolumn{2}{|c|}{ Eksport } & \multicolumn{4}{c|}{ PKB } \\
\cline { 2 - 7 } & & \multicolumn{2}{|c|}{ ogółem } & \multicolumn{2}{c|}{ per capita } \\
\cline { 2 - 7 } & $1990-2000$ & $2000-2010$ & $1990-2000$ & $2002-2010$ & $1990-2000$ & $2000-2010$ \\
\hline Azja & 9,53 & 14,81 & 6,24 & 7,23 & 4,65 & 5,98 \\
\hline Ameryka & 10,57 & 11,28 & 3,13 & 3,62 & 1,41 & 2,34 \\
\hline Afryka & 3,25 & 16,45 & 2,58 & 5,34 & 0,06 & 2,80 \\
\hline $\begin{array}{l}\text { Afryka } \\
\text { Północna }\end{array}$ & 2,77 & 16,11 & 2,82 & 4,86 & 1,14 & 3,35 \\
\hline $\begin{array}{l}\text { Afryka } \\
\text { Subsaharyjska }\end{array}$ & 3,46 & 16,61 & 2,46 & 5,58 & $-0,24$ & 2,84 \\
\hline
\end{tabular}

Źródło: UNCTAD statistical database...

Biorąc pod uwagę sytuację poszczególnych subregionów, warto zauważyć, że stało się to możliwe głównie dzięki wynikom osiąganym przez kraje Afryki Subsaharyjskiej, które w mniejszym stopniu odczuły skutki światowego kryzysu finansowo-gospodarczego. Ponadto w przypadku Afryki Północnej przyczyn nieco słabszych wyników należy także upatrywać w utrzymywaniu dość silnych związków instytucjonalnych z Unią Europejską przez większość krajów tego regionu.

${ }^{11}$ W 2012 roku udział ten jeszcze wzrósł do ponad 3,4\%, ale już w następnym roku spadł do 3,2\%. Z kolei w wypadku krajów Afryki Subsaharyjskiej spadek odnotowano zarówno w 2012, jak w 2013 roku (do 2,27\%).

${ }_{12}$ Por. J. Dudziński, J. Narękiewicz, Nowe relacje cen $w$ handlu międzynarodowym a kierunki rozwoju eksportu krajów Afryki, „International Business and Global Economy” nr 34, Wydawnictwo Uniwersytetu Gdańskiego, Gdańsk 2014, s. 703. 


\section{Ceny dóbr podstawowych a sytuacja gospodarcza krajów afrykańskich od 2012 roku}

Tendencje cen surowców i żywności na rynku międzynarodowym uległy wyraźnej zmianie od 2011 roku (por. rysunek 2). Ceny światowe dóbr podstawowych w latach 2012-2013 ustabilizowały się, osiągając 85\%-90\% maksymalnego poziomu zanotowanego w II kwartale 2011 roku. W połowie 2014 roku zanotowano silny spadek cen, widoczny szczególnie w przypadku metali (69\% poziomu z II kwartału 2011 r.). Łączny wskaźnik cen surowców i żywności liczony przez IMF wykazał w tym okresie zniżkę o $13 \%$, a bez paliw o blisko $19 \%{ }^{13}$.

Rysunek 2. Ceny towarów w handlu międzynarodowym w latach 2011-2014

(II kwartał $2011=100)$

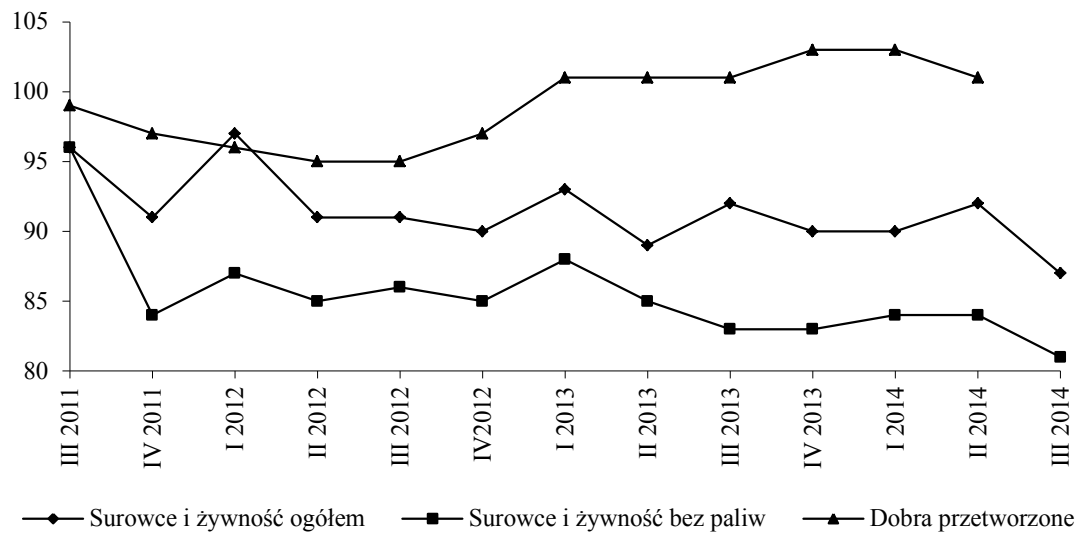

Źródło: http://unstats.un.org/unsd/trade/imts/tables/Table40-2014-Sep.xls (dostęp 20.11.2014); www.imf/external//np/res/commod/table1.pdf (dostęp 20.11.2014).

Należy zarazem podkreślić, że oznaczało to odwrócenie obserwowanego wcześniej procesu poprawy relacji cen surowców i żywności w stosunku do cen dóbr przetworzonych (por. rysunek 2). Wskaźnik cen dóbr przetworzonych w eksporcie krajów rozwiniętych gospodarczo - mimo występującego w analizowanym okresie wzmocnienia USD - wykazał nawet bezwzględny wzrost (o 1\%), a łączny wskaźnik cen tych wyrobów obniżył się bardzo nieznacznie (o 3\%). Wiąże się to

\footnotetext{
${ }^{13}$ Szacunki własne na podstawie danych IMF.
} 
z coraz większym udziałem krajów rozwijających się w łącznym światowym eksporcie produktów przemysłu przetwórczego.

Ukazane tendencje i relacje cenowe mają się też utrzymać - jak wskazują istniejące prognozy - w następnym roku. Zgodnie z prognozą IMF, ceny paliw w 2015 roku zwiększą się o 3,3\%, a towarów nienaftowych o 4,1\% (w tym żywność o blisko 8\%). Mają więc spadać w tempie wielokrotnie szybszym niż zakładana niewielka obniżka cen dóbr przetworzonych (o $0,5 \%$, por. tabela 2). Warto w tym kontekście podkreślić, że obserwowany w drugiej połowie 2014 roku spadek cen ropy naftowej był jednak znacznie głębszy niż wskazywały wspomniane prognozy (w listopadzie 2014 roku cena ropy WTI wyniosła zaledwie 73, a Brent około 78 USD za baryłkę) $)^{14}$.

Tabela 2. Dynamika cen w handlu międzynarodowym w latach 2010-2015 (na bazie USD, w \%)

\begin{tabular}{|l|r|r|r|r|r|c|}
\hline \multicolumn{1}{|c|}{ Grupy towarowe } & 2010 & 2011 & 2012 & 2013 & $2014^{*}$ & $2015^{*}$ \\
\hline Paliwa & 27,9 & 31,6 & 1,0 & $-0,9$ & $-1,3$ & $-3,30$ \\
\hline Towary nienaftowe, w tym: & 26,5 & 17,9 & $-10,0$ & $-1,2$ & $-3,0$ & $-4,10$ \\
\hline \multicolumn{1}{|c|}{ żywność } & 11,9 & 19,9 & $-2,4$ & 1,1 & $-4,1$ & $-7,90$ \\
\hline metale & 48,2 & 13,5 & $-16,8$ & $-4,3$ & $-7,5$ & $-0,18$ \\
\hline Wyroby przetworzone & 2,3 & 6,0 & 0,4 & $-1,1$ & $-0,2$ & $-0,50$ \\
\hline
\end{tabular}

${ }^{*}$ Prognoza.

Źródło: World Economic Outlook, October 2014, IMF, Washington 2014, s. 197.

Przedstawione tendencje cenowe są oczywiście niekorzystne dla eksporterów surowców i żywności, w tym zwłaszcza - w silnie uzależnionej od ich wywozu Afryce. Bardzo dobitnie zilustrowano to zjawisko na wykresie, na którym przedstawiono dynamikę cen eksportowych i wartości wywozu Afryki w latach 2011-2014. Dynamika wartości eksportu Afryki w 2012 roku obniżyła się aż trzykrotnie (w stosunku do 2011 roku), a w 2013 roku wartość eksportu nawet bezwzględnie spadła (o 6,3\%) $)^{15}$.

Wskazane wcześniej zniżki cen światowych surowców i żywności spowodowały nawet spadek bezwzględny cen eksportowych (o 4,4\% w 2012 roku i o 2,2\%

\footnotetext{
14 Dane IMF oraz A. Kublik, Kreml walczy o ceny ropy, „Gazeta Wyborcza” z 25.11.2014 r.

${ }^{15}$ UNCTAD statistical database...
} 
w 2013 roku). Zgodnie z istniejącymi prognozami należy oczekiwać dalszego spadku tych cen w IV kwartale 2014 roku i w 2015 roku.

Niekorzystny dla krajów afrykańskich ruch cen na rynku międzynarodowym, pogarszający dynamikę ich eksportu, przyczyniał się zarazem do wzrostu ujemnego salda obrotów z zagranicą. Dobitnie ilustrują to dane w tabeli 3 ukazującej kształtowanie się salda obrotów bieżących (na przykładzie silniej uzależnionej od eksportu surowców i żywności Afryki Subsaharyjskiej). Ujemne saldo krajów tego subregionu Afryki zwiększyło się w 2012 roku ponad trzykrotnie w stosunku do 2011 roku. Jego dalsze pogorszenie zanotowano także w 2013 roku, a prognozy na obecną dekadę są szczególnie niepokojące. Według szacunków IMF, ujemne saldo obrotów bieżących w 2019 roku ma być bowiem niemal ośmiokrotnie większe niż w 2011 roku (por. tabela 3), przy czym tempo przewidywanego wzrostu jest nawet wyższe niż zakładana zwyżka ujemnego salda całej grupy krajów o niskim dochodzie (low income countries).

Tabela 3. Saldo rachunku obrotów bieżących wybranych regionów i krajów w latach 2011-2019 (mld USD)

\begin{tabular}{|l|r|r|r|r|r|r|}
\hline \multicolumn{1}{|c|}{ Wyszczególnienie } & 2011 & 2012 & 2013 & $2014^{*}$ & $2015^{*}$ & $2019^{*}$ \\
\hline Kraje rozwinięte gospodarczo & $-80,8$ & $-45,1$ & 181,6 & 125,2 & 93,7 & 95,2 \\
\hline \multicolumn{1}{|c|}{ USA } & $-459,3$ & $-460,8$ & $-400,3$ & $-430,9$ & $-483,6$ & $-615,3$ \\
\hline $\begin{array}{l}\text { Kraje rozwijające się } \\
\text { i o gospodarkach wschodzących }\end{array}$ & 416,9 & 387,9 & 231,2 & 229,9 & 176,9 & 163,8 \\
\hline$\quad$ Chiny & 136,1 & 215,4 & 182,8 & 185,3 & 220,6 & 459,0 \\
\hline \multicolumn{1}{|c|}{ Afryka Subsaharyjska } & $-9,6$ & $-30,7$ & $-38,5$ & $-43,3$ & $-57,2$ & $-78,6$ \\
\hline
\end{tabular}

*Prognoza.

Źródło: World Economic Outlook..., s. 199.

Wspomniana wcześniej silna zależność między ruchem cen surowców i żywności a dynamiką wzrostu gospodarczego krajów będących ich eksporterami znajduje zatem potwierdzenie również w analizowanym obecnie okresie. W bieżącej dekadzie zanotowano znaczne osłabienie tempa wzrostu gospodarczego w wszystkich regionach gospodarki światowej. Jakkolwiek silniej uwidoczniło się ono w krajach rozwiniętych gospodarczo, to jednak występuje wyraźnie także w krajach rozwijających się (obniżenie tempa wzrostu PKB per capita z 6,3\% w 2010 roku do 3,2\% 
w 2013 roku $)^{16}$. Stosunkowo najsłabiej odczuwalne osłabienie zanotowano w krajach rozwijających się Azji. Region ten odznacza się jednak relatywnie mniejszą zależnością od eksportu surowców i żywności.

Wyraźne osłabienie tempa wzrostu gospodarczego zanotowano również w Afryce, co wydaje się zrozumiałe w świetle dużej zależności tego regionu od eksportu dóbr podstawowych. Na podkreślenie zasługuje fakt wyraźnego bezwzględnego spadku PKB per capita w 2011 roku (o 1,62\%) ${ }^{17}$. Pewien wpływ mogły tu mieć jednak także czynniki o charakterze społeczno-politycznym. Znaczne osłabienie tempa wzrostu gospodarczego zanotowano także w Ameryce Łacińskiej, regionie charakteryzującym się jednak również silną - i rosnącą w XXI wieku - zależnością od wywozu surowców i żywności.

W świetle powyższych uwag całkowicie zrozumiałe stają się coraz szerzej przedstawione w literaturze światowej, a zwłaszcza w opracowaniach UNCTAD, postulaty powrotu do aktywnej polityki przemysłowej (industrializacji). Jak wcześniej wskazywano, w I dekadzie XXI wieku nastąpiło bowiem w praktyce wyraźne odejście od tej praktyki w zdecydowanej większości krajów rozwijających się ${ }^{18}$. Wspomniana problematyka konieczności silniejszej dywersyfikacji eksportu krajów rozwijających się i prowadzenia aktywnej polityki przemysłowej (reindustrializacja gospodarki) znalazła poczesne miejsce w ostatnim raporcie UNCTAD dotyczącym światowego handlu i rozwoju ${ }^{19}$. Przy czym - co interesujące - eksperci UNCTAD podkreślają konieczność prowadzenia polityki reindustrializacji nie tylko w krajach rozwijających się, ale również w rozwiniętych gospodarczo (USA, UE) ${ }^{20}$.

W przypadku krajów rozwijających się rozwój przemysłu przetwórczego umożliwiałby odwrócenie dotychczasowej negatywnej tendencji wyrażającej się

${ }^{16}$ Ibidem.

${ }^{17}$ Negatywne skutki wahań cen surowców i żywności w gospodarce Afryki przedstawione są m.in. w opracowaniu A. Sarris, Food Commodity Price Volatility and Policy in Light of Africa's Agricultural Transformation, National and Kapodistrian University of Athens, Ateny 2014, s. 6 i n.

${ }_{18}$ Por. np. J. Mayer, P. Fajarnes, Triplin Africa's Primary Exports: What, How, Were?, „The Journal of Development Studies” 2008, Vol. 44, Issue 1; M. Czarnecka-Gallas, The Efficiency of Industrial Policy in 21 $1^{\text {st }}$ Century? The Case of Brazil, „Gospodarka Narodowa” 2013, $\mathrm{nr}$ 7-8; Latin America and the Caribbean in the World Economy 2011-2012. Continuing Crisis in the Centre and New Opportunities for Developing Economies, United Nations, ECLAC, Santiago (Chile) 2012.

19 Por. Trade and Development Report 2014, UNCTAD, New York-Geneva 2014, rozdz. IV i V.

${ }^{20}$ Ibidem, s. 93-96. 
w przepływie zasobów siły roboczej do dziedzin mniej produktywnych - czyli górnictwa i rolnictwa (Afryka i Ameryka Łacińska) ${ }^{21}$. Przy okazji eksperci UNCTAD zwracają jednak uwagę na fakt, aby nie traktować uczestnictwa w tzw. międzynarodowych sieciach produkcyjnych (international production network) jako szybkiej ścieżki (fast track) uprzemysłowienia. Wskazują bowiem, że dominujący obecnie model powiązań produkcyjnych, w postaci wspomnianych sieci, jest wysoce niesymetryczny. Przynosi on bowiem zyski przede wszystkim jednej stronie, tj. korporacjom przemysłowym z krajów rozwiniętych gospodarczo. W tym kontekście na szczególne wyeksponowanie zasługuje fakt, że Chiny - będąc największym światowym producentem w sektorze elektroniki - posiadają udział w zyskach tego sektora wynoszący zaledwie $3 \%{ }^{22}$.

W efekcie mamy do czynienia z sytuacją, w której relacja krajowej wartości dodanej (domestic value added) do PKB w krajach rozwijających się, eksportujących głównie wyroby podstawowe, jest paradoksalnie znacznie większa od tej, którą uzyskuje się z produkcji przemysłowej realizowanej w formie międzynarodowych sieci produkcyjnych ${ }^{23}$. Stąd też eksperci UNCTAD proponują rozwój produkcji w ramach regionu w postaci tzw. south-south production network. Są one obecnie wprawdzie dość słabo rozwinięte, jednak istnieje wiele argumentów przemawiających za ich silniejszą ekspansją w przyszłości.

\section{Podsumowanie}

Tradycyjnie głoszone w teorii ekonomii poglądy wskazywały na konieczność dywersyfikacji eksportu i gospodarki (rozwój przemysłu przetwórczego i sektora usług) krajów rozwijających się jako najlepszej metody ograniczenia skutków pogarszania się terms of trade. Bardzo dobre - bezwzględnie i relatywnie - wyniki gospodarcze krajów o surowcowo-rolnej orientacji wywozu w pierwszej dekadzie XXI wieku (co było najlepiej widoczne na przykładzie państw afrykańskich) spowodowały pojawienie się głosów o konieczności rewizji tradycyjnego podejścia do kierunków rozwoju ekonomicznego krajów o surowcowo-rolnej orientacji wywozu.

${ }^{21}$ Ibidem, s. 97.

${ }^{22}$ Por. S. Starrs, The Chimera of Global Convergence, „New Left Review”, May/June 2014, No. 87, s. 91.

${ }^{23}$ Por. Trade and Development Report 2014..., s. 105. 
Sytuacja panująca w obecnej dekadzie, a także przedstawiane prognozy cen i tempa rozwoju ekonomicznego wskazują jednak na znaczną aktualność tez tradycyjnego podejścia ekonomicznego. Znajdują one także potwierdzenie w najnowszych raportach organizacji międzynarodowych (UNCTAD, IMF). We wspomnianych opracowaniach zwraca się jednak uwagę także na wady uprzemysłowienia krajów rozwijających się w formie tzw. międzynarodowych sieci produkcyjnych, postulując szerszy rozwój wewnątrzregionalnych, zarówno o charakterze handlowym, jak i produkcyjnym.

\section{Literatura}

Budnikowski A., Międzynarodowe stosunki gospodarcze, PWE, Warszawa 2001.

Commodities and Development Report, UNCTAD, New York-Geneva 2012.

Commodity Dependence and International Commodity Prices, w: Towards Human Resilience: Sustaining MDG Progress in an Age of Economic Uncertainty, UNDP, New York 2011.

Commodity Markets Review, IMF, October 2013.

Czarnecka-Gallas M., The Efficiency of Industrial Policy in 21 $1^{\text {st }}$ Century? The Case of Brazil, „Gospodarka Narodowa” 2013, No. 7-8.

Dudziński J., Ceny rynku międzynarodowego. Tendencje i mechanizm, Wydawnictwo Naukowe Uniwersytetu Szczecińskiego, Szczecin 1998.

Dudziński J., Narękiewicz J., Nowe relacje cen w handlu międzynarodowym a kierunki rozwoju eksportu krajów Afryki, „International Business and Global Economy” nr 34, Wydawnictwo Uniwersytetu Gdańskiego, Gdańsk 2014.

Evaluation on Terms of Trade, w: Trade and Development Report, UNCTAD, New YorkGeneva 2005.

Excessive Commodity Price Volatility: Macroeconomic Effects on Growth and Policy Options, UNCTAD, 30 April 2012.

Kublik A., Kreml walczy o ceny ropy, „Gazeta Wyborcza” z 25.11.2014 r.

Latin America and the Caribbean in the World Economy 2011-2012. Continuing Crisis in the Centre and New Opportunities for Developing Economies, United Nations, ECLAC, Santiago (Chile) 2012.

Mayer J., Fajarnes P., Triplin Africa's Primary Exports: What, How, Were?, „The Journal of Development Studies" 2008, Vol. 44, Issue 1.

Nissanke M., Commodity Markets and Excess volatility: Sources and Strategies to Reduce Adverse Development Impacts, CFC, University of London, London 2011. 
Ocampo J.A, Parra M., The Terms of Trade for Commodities in the Twentieth Century, „CEPAL Review” No. 79, April 2003.

Page S., Hewitt A., World Commodity Prices: Still a Problem for Developing Countries?, Overseas Development Institute, London 2011.

Price Volatility in Food and Agriculture Markets: Policy Responses, FAO, 2 June 2011.

Sarris A., Food Commodity Price Volatility and Policy in Light of Africa's Agricultural Transformation, National and Kapodistrian University of Athens, Ateny 2014.

Spatafora N., Tytell I., Commodity Terms of Trade: The History of Booms and Busts, „IMF Working Paper", September 2009.

Trade and Development Report 2005, UNCTAD, New York-Geneva 2005.

Trade and Development Report 2014, UNCTAD, New York-Geneva 2014.

UNCTAD statistical database, http://unctadstat.unctad.org (dostęp 20.11.2014).

World Economic Outlook, October 2014, IMF, Washington 2014.

\title{
DIRECTIONS OF CHANGES IN INTERNATIONAL TRADE AND THE ECONOMY IN DEVELOPING COUNTRIES IN THE $21^{\text {ST }}$ CENTURY (BASED ON THE EXAMPLE OF AFRICA)
}

\begin{abstract}
In the paper an attempt is made to assess the impact of price changes in the international trade on the economy of developing countries and on the export potential of countries rich in natural resources and food (especially in Africa) in the $21^{\text {st }}$ century. The new price relations witnessed in the years 2003-2011 involved significantly more dynamic price rises of primary commodities than it was observed for manufactured goods but this trend reversed in 2012.

The research shows that developing countries are significantly more dependent on the exports of primary commodities than developed economies, and as such they are more sensitive to changes in these prices. Following very good economic results of the African economies in the $2000 \mathrm{~s}$, voices have emerged claiming that the traditional approach to the directions of economic growth in countries exporting mostly primary commodities should be revised. The present tendencies as well as the outlook for prices and economic growth show, however, that the traditional economic approach still holds true today.
\end{abstract}

Translated by Joanna Bajera

Keywords: world prices, African countries, export diversification

JEL codes: F10, F14 
